\title{
PENGARUH PANDEMI TERHADAP TATA KELOLA PEMERINTAHAN; STUDI KASUS PELAYANAN PUBLIK PEMERINTAH PROVINSI LAMPUNG
}

\section{INFLUENCE OF PANDEMIC ON GOVERNANCE; CASE STUDY OF LAMPUNG PROVINCE GOVERNMENT PUBLIC SERVICES}

\author{
Ridwan Saifuddin \\ Peneliti Balitbangda Provinsi Lampung \\ Email : bumikitasatu@gmail.com
}

Dikirim 22 September 2021, Direvisi 12 Oktober 2021, Disetujui 29 November 2021

\begin{abstract}
Abstrak: Pandemi Covid-19 telah berdampak pada penyelenggaraan pelayanan publik. Berbagai penyesuaian dan penataan telah dilakukan perangkat daerah yang memberikan layanan publik di lingkungan Pemda Provinsi Lampung. Kapasitas organisasi perangkat daerah khususnya yang terkait dengan pelayanan publik di masih harus ditingkatkan. Identifikasi dampak dan alternatif respon yang penting dilakukan organisasi pelayanan publik dalam menghadapi pandemi ini dikaji dengan menggunakan metode penelitian kualitatif. Hasil wawancara menggunakan kuesioner dengan responden ASN pemberi layanan publik di lingkungan Pemda Provinsi Lampung menunjukkan, kendala utama dalam meningkatkan kualitas pelayanan publik yang penting segera diatasi adalah terkait kapasitas SDM aparatur, sarana-prasarana penunjang pelayanan publik, pemanfaatan teknologi informasi dan komunikasi yang lebih optimal, serta komitmen pemimpin dalam mewujudkan organisasi dan pelayanan publik yang lebih berkualitas. Tata kelola terintegrasi dan investasi yang tepat dalam aspek sumber daya manusia, teknologi, dan manajerial semakin mendesak diwujudkan. Mekanisme interaksi dan keterhubungan antara penyedia dan pengguna layanan publik juga masih perlu ditingkatkan, sehingga diharapkan membuat pemerintah dan masyarkat menjadi lebih dekat, sinergi bisa lebih kuat, dan inisiatif baru lebih terfasilitasi. Publik perlu lebih terlibat dalam upaya perbaikan mutu pelayanan publik yang diberikan pemerintah.
\end{abstract}

Kata kunci: Covid-19, pelayanan publik, kepuasan, teknologi, krisis, pandemi.

\begin{abstract}
The COVID-19 pandemic has had an impact on the delivery of public services. Various adjustments and arrangements have been made by regional apparatus that provide public services within the Lampung Provincial Government. The capacity of regional apparatus organizations, especially those related to public services, still needs to be improved. The identification of impacts and alternative responses that are important for public service organizations in dealing with this pandemic is reviewed using qualitative research methods. The results of interviews using questionnaires with civil servant respondents who provide public services in the local government of Lampung Province show that the main obstacles in improving the quality of public services that are important to be addressed immediately are related to the capacity of human resources of the apparatus, supporting infrastructure for public services, utilization of information and communication technology that is more optimal, and commitment of leaders in realizing higher quality organizations and public services. Integrated governance and proper investment in human resources, technology, and managerial aspects are increasingly urgent to be realized. The mechanism of interaction and connectivity between providers and users of public services also still needs to be improved, so that it is hoped that the government and the community will be closer, synergies can be stronger, and new initiatives will be more facilitated. The public needs to be more involved in efforts to improve the quality of public services provided by the government.
\end{abstract}

Keywords: Covid-19, public services, satisfaction, technology, crisis, pandemic. 


\section{PENDAHULUAN}

Penghujung 2019, Organisasi Kesehatan Dunia (WHO) merilis munculnya pneumonia jenis baru. Penyebabnya belum diketahui. Infeksi pernapasan akut yang menyerang paru-paru itu terdeteksi di Kota Wuhan, Provinsi Hubei, China. Belum genap sebulan, pada 13 Januari 2020, dikabarkan kasus serupa pertama di luar China terjadi di Thailand. Beberapa hari kemudian, 29 Januari 2020, virus itu dikabarkan sudah menjangkau Timur Tengah. Sejak itu, jumlah kasus terus bertambah, menyebar ke berbagai negara. Baru pada 11 Februari 2020, WHO mengumumkan penyakit baru itu adalah Corona Virus Disease 2019 (Covid-19).

Di Indonesia, kasus positif Covid-19 muncul pertama kali pada 2 Maret 2020, seorang wanita di Kota Depok, Jawa Barat. Pada bulan yang sama, wabah itu sampai di Provinsi Lampung. Ketua Gugus Tugas Penanggulangan Covid-19 Achmad Yurianto, menyampaikan kabar itu dalam konferensi pers 18 Maret 2020, di Jakarta. Korban meninggal pertama akibat Covid19 di Lampung, terjadi pada 30 Maret 2020. Seorang laki-laki 35 tahun (Pasien 02), warga Kota Bandar Lampung, berstatus Aparatur Sipil Negara (ASN) di lingkungan Pemerintah Provinsi Lampung. Setelah sempat dirawat beberapa hari di RSU Abdoel Moeloek. Wabah telanjur menyebar ke banyak negara dan daerah di Indonesia. Berbagai sektor terdampak (Saifuddin, 2020: 271).

Sejak pandemi itu, pemerintah dan kalangan medis menyosialisasikan protokol kesehatan, yaitu memakai masker, mencuci tangan, menjaga jarak, menghindari kerumunan, dan mengurangi mobilitas. Protokol kesehatan ini diberlakukan baik dalam aktivitas perkantoran, sosial, kemasyarakatan, perekonomian, hingga pelayanan publik. Protokol kesehatan dipercaya menjadi cara paling tepat untuk menekan dan mengatasi penyebaran wabah.
Meski terlihat membangun kebiasaan baru sering kali tidak mudah. Pelanggaran protokol kesehatan masih banyak dijumpai di berbagai tempat dan acara.

Aktivitas pemerintahan khususnya dalam pelayanan publik juga terpengaruh wabah ini. Fasilitas baru disediakan, agar masyarakat pengguna layanan disiplin menerapkan protokol kesehatan, seperti menyediakan tempat cuci tangan, mencegah terjadinya kerumunan di tempattempat layanan, sampai dengan menerapkan aplikasi digital untuk meminimalisir tatap muka langsung antara pemberi layanan dan pengguna layanan.

Pemerintah juga cukup tanggap dalam menyikapi pandemi, dengan menerbitkan sejumlah regulasi, mulai dari peraturan pemerintah pengganti undang-undang, peraturan pemerintah, keputusan presiden, instruksi presiden, peraturan menteri, keputusan menteri, surat edaran menteri, juga peraturan dan keputusan lembaga terkait, seperti dari Otoritas Jasa Keuangan (OJK), Gugus Tugas Percepatan Penanggulangan Covid-19, Badan Nasional Penanggulangan Bencana (BNPB), hingga Fatwa Majelis Ulama Indonesia (MUI) tentang Penyelenggaraan Ibadah dalam Situasi Terjadi Wabah Covid-19. Pemerintah daerah pun tak kalah gesit membuat aturan-aturan baru, baik berupa surat edaran, instruksi, hingga peraturan kepala daerah, yang juga dimaksudkan untuk menekan penyebaran wabah ini.

Tata kelola pemerintahan dan pelayanan publik yang selama ini relatif ajek, terlihat gamang atau tidak siap dalam menghadapi Pandemi Covid-19. Kondisi ini juga dialami banyak organisasi di dunia pemerintah maupun swasta. Pandemi memaksa kita melakukan penyesuaian dan perubahan. Pertanyaannya tentu, perubahan seperti apa yang akan kita tuju? Apakah perubahan itu menyentuh aspek fundamental dalam menciptakan tata kelola yang lebih relevan, atau hanya sementara, 
lalu kita kembali pada tata kelola dan kebiasaan seperti sebelum pandemi terjadi?

Sementara ini, pola dan tata kerja pemerintahan dan pelayanan publik berubah akibat pandemi. Kegiatan di tempat terbuka, seperti olahraga, upacara, atau apel pagi yang biasanya rutin dilaksanakan instansi terhenti. Suasana yang tak biasa di lingkungan kantor Pemerintah Provinsi Lampung itu, terlihat sejak diumumkan kasus positif Covid-19 pertama di daerah ini, pada 18 Maret 2020. Berbagai aktivitas birokrasi selama pandemi menyesuaikan protokol kesehatan. Ketentuan hari dan jam kerja ASN, sebagaimana diatur PP Nomor 53 Tahun 2010 tentang Disiplin Pegawai Negeri Sipil, sementara dikesampingkan. Sistem piket sempat diterapkan di setiap satuan kerja. Pemerintah pusat dan daerah membuat keputusan menerapkan kebijakan bekerja dari rumah (WFH) bagi ASN. Semakin lazim pertemuan-pertemuan dan rapat virtual. Berbagai layanan publik juga mengadaptasi protokol kesehatan, terutama dengan menghindari kerumunan (jaga jarak), memakai masker, dan menyediakan sarana cuci tangan di setiap tempat layanan publik.

Keputusan Menteri Dalam Negeri Nomor 440-830 Tahun 2020 tentang Pedoman Tatanan Normal Baru Produktif dan Aman Corona Virus Disease 2019 bagi Aparatur Sipil Negara di Lingkungan Kementerian Dalam Negeri dan Pemerintah Daerah, menegaskan agar pemerintah daerah tetap memberikan pelayanan maksimal kepada masyarakat. Kesiapan pemerintah daerah tersebut, meliputi kapasitas layanan kesehatan; penyediaan sarana dan prasarana pelayanan pemerintahan yang mudah diakses masyarakat; kesiapan pengelolaan sosial politik dan komunikasi publik pemerintah daerah; serta kesiapan pembangunan jejaring masyarakat berbasis desa/kelurahan.
Pandemi mengubah cara kerja organisasi dan kehidupan jutaan orang di dunia. Termasuk cara kerja birokrasi. Pertanyaan penelitian yang dicari jawabannya melalui kajian ini adalah, bagaimana organisasi perangkat daerah (OPD) di lingkungan Pemerintah Provinsi Lampung, khususnya yang terkait pelayanan publik merespon dinamika lingkungan selama masa pandemi, baik pada tataran teknis terkait kapasitas fungsional dalam pemberian pelayanan publik, tingkat manajerial terkait kemampuan merancang strategi dan pendekatan dalam pemberian layanan publik, serta tingkat kelembagaan terkait kemampuan organisasi dalam merespon lingkungan yang berubah? Bagaimana pula pengaruh Pandemi Covid-19 terhadap upaya peningkatan kapasitas (capacity building) organisasi perangat daerah pelayanan publik, serta bagaimana pemerintah daerah sebaiknya memanfaatkan momentum pandemi ini untuk mendorong peningkatan kapasitas organisasi dalam mempercepat perwujudan janji kerja reformasi birokrasi (janji kerja 32) dan pencapaian visi Lampung Berjaya.

\section{METODOLOGI}

Penelitian ini menggunakan metode penelitian kualitatif dengan pendekatan fenomenologi. Mempergunakan data skunder berupa berbagai regulasi terkait tata kelola pemerintahan dan literatur lainnya, serta data primer berupa hasil observasi dan jajak pendapat menggunakan kuesioner yang melibatkan responden dari ASN di OPD pelayanan publik di lingkungan Pemerinah Provinsi Lampung.

Fenomenologi berusaha mencari pemahaman bagaimana manusia mengonstruksi makna dan konsep penting dalam kerangka intersubyektivitas (pemahaman individu mengenai dunia yang dibentuk dari hubungan individu dengan individu lainnya) (Kuswarno, 2009:2). Alfred Schutz berpendapat, fenomenologi sosial mengkaji tentang intersubyektivitas. 
Studi intersubyektivitas adalah upaya untuk menjawab pertanyaan-pertanyaan, seperti: Bagaimana kita mengetahui motif, keinginan, dan makna tindakan orang lain? Bagaimana kita mengetahui makna atas keberadaan orang lain? Bagaimana kita dapat mengerti dan memahami atas segala sesuatu secara mendalam? Bagaimana hubungan timbal balik itu dapat terjadi?

Secara etimologis, asal kata fenomenologi dari phenomenon yang berarti realitas yang tampak, dan logos yang berarti ilmu, sehingga fenomenologi diartikan sebagai ilmu untuk mendapatkan penjelasan dari realitas yang tampak. Fenomena yang tampak itu adalah refleksi dari realitas yang tidak dapat berdiri sendiri, karena ia memiliki makna dan konteks yang mengundang penafsiran lebih lanjut. Fenomenologi berasumsi bahwa orang-orang secara aktif menginterpretasikan pengalamanpengalamannya dan mencoba memahami dunia dengan pengalaman pribadinya tersebut (Little John, 2009:57). Edmund Husserl tercatat sebagai pelopor istilah fenomenologi, yang kemudian dipolerkan oleh Johann Heirinckh.

Pricewaterhouse Coopers ( $\mathrm{PwC})$, sebuah kantor jasa profesional terbesar di dunia, melakukan survei tentang respon komunitas bisnis di seluruh dunia terhadap krisis global paling mengganggu: Pandemi Covid-19. Bagaimana perusahaan bereaksi, apa yang telah dipelajari, dan bagaimana mereka mempersiapkan diri untuk masa depan, menjadi fokus survei yang dirilis pada Maret 2021 lalu. PwC's Global Crisis Survey 2021 tersebut dilakukan antara 20 Agustus 2020 s.d. 25 Januari 2021, melibatkan lebih dari 2.800 pemimpin bisnis dari 73 negara dan 29 industri, untuk merangcang peta jalan ketahanan pascapandemi ini.

Survei ini menghasilkan potret menarik tentang taktik, alat, dan proses yang diterapkan organisasi, serta apa yang berhasil dan apa yang tidak, serta mengapa.
Dari mengubah strategi perusahaan hingga dengan cepat membentuk kembali kemampuan produksi, dan bagaimana organisasi bereaksi? Bagaimana bisnis mengintegrasikan apa yang telah mereka pelajari sebelumnya ke dalam strategi ketahanan untuk jangka waktu panjang?

Survei Krisis Global 2021 ini merupakan tindak lanjut dari analisis krisis perusahaan sebelumnya yang telah diterbitkan pada 2019. Dalam survey krisis 2019 (sebelum pandemi) tersebut diungkapkan bahwa, sebanyak 95\% responden percaya bahwa krisis akan segera terjadi dalam dua tahun ke depan. Namun, tidak ada potensi krisis semacam pandemi Covid-19 ini yang berhasil diindentifikasi dalam survey 2019 tersebut. Dengan kata lain, krisis pandemi merupakan ancaman yang tidak terdeteksi sebelumnya, dan ini yang menurut para pemimpin bisnis sangat dikhawatirkan. Virus mematikan yang memicu gangguan di seluruh dunia ini tidak muncul di "layar radar" mereka.

Tantangan manajemen krisis (dan manajemen risiko) memang bukan semata untuk memprediksi atau mengukur setiap insiden spesifik yang berpotensi memengaruhi bisnis atau organisasi pada masa mendatang, melainkan bagaimana bisnis atau organisasi memprioritaskan dan berinvestasi dalam membangun fondasi ketahanan dalam rangka mengatasi beraneka jenis potensi krisis yang mungkin dihadapi. Harapannya tentu dengan manajemen krisis yang baik, organisasi akan memiliki posisi yang lebih kuat dalam menghadapi apa yang akan terjadi selanjutnya, yang sangat mungkin tidak termonitor sebelumnya.

Tiga kesimpulan penting yang diungkapkan berdasarkan tanggapan 2.800 responden dari kalangan pemimpin bisnis di seluruh dunia dalam $P w C$ 's Global Crisis Survey 2021 tersebut adalah, bahwa kesiapan, ketangkasan, rencana/desain 
respons krisis yang terintegrasi, serta ketahanan organisasi sangat penting. Organisasi niscaya akan menghadapi krisis demi krisis, dari waktu ke waktu. Itu semua tetap penting dan relevan untuk diperhatikan organisasi, bahkan ketika sekarang kita sedang berada dalam zona pandemi Covid-19, dan juga nanti setelah pandemi dapat diatasi. Organisasi yang memiliki rencana respons krisis strategis akan mampu melakukan mobilisasi sumber daya lebih cepat, menstabilkan operasi bisnis, dan merespons secara efektif gelombang kejutan-gangguan.

Pada 2019, 95\% responden Survei Krisis Global PwC yang pertama mengatakan bahwa mereka memperkirakan akan terjadi krisis dalam dua tahun ke depan. Namun, ketika pandemi Covid-19 melanda, lebih dari $30 \%$ responden survei itu tidak siap dan tidak memiliki tim tanggapan krisis inti yang solid. Setahun kemudian (2020), "pesan" krisis itu akhirnya sampai. Secara luar biasa, $95 \%$ pemimpin bisnis melaporkan bahwa mereka merasakan kebutuhan segera untuk meningkatkan kemampuan manajemen krisis mereka. Perencanaan dirasakan harus lebih strategis, cermat, dan cepat. Terlepas dari gangguan besar-besaran yang menimbulkan korban akibat pandemi Covid-19 ini, setidaknya terdapat $20 \%$ organisasi yang melaporkan bahwa krisis justru telah berdampak positif secara keseluruhan pada bisnis mereka, pandemi telah melatih "otot-otot tanggap" krisis yang lebih baik.

Dampak positif pandemi yang dibuktikan dengan membaiknya posisi keuangan dan nilai para pemegang saham, justru telah dirasakan setidaknya oleh lebih dari setengah responden. Mereka merasakan langsung dampak baik dari pandemi, karena mereka memiliki tim krisis yang solid dan berdedikasi tinggi, serta tangkas dalam mendorong respons, memperkuat manajemen krisis organisasi, sekaligus keputusan cepat dan efektif terhadap krisis yang dirasakan. Selain tim yang terdefinisi dengan baik, organisasi memerlukan program tangkas yang fleksibel mengatasi berbagai kemungkinan dan jenis krisis di kemudian hari. Sayangnya, hanya $35 \%$ responden memiliki rencana respons krisis yang baik. Sebagian besar organisasi tidak merancang manajemen mereka untuk menjadi "anti krisis" sebagai ciri khas organisasi yang tangguh.

PwC's Global Crisis Survey 2021 juga merekomendasikan apa yang harus dilakukan bisnis hari ini, untuk bersiap menghadapi gangguan yang tak terhindarkan berikutnya? Diantaranya, dibutuhkan tim tanggap krisis untuk memimpin respons saat krisis terjadi. Saat krisis melanda, tim ini yang akan memobilisasi dan beradaptasi dengan cepat, menjalankan rencana yang telah diuji dan sempurnakan, sekaligus menjaga agar operasional organisasi terus berjalan. Di samping itu, perlu dirancang rencana respons krisis yang selaras dengan strategi, sasaran, dan tujuan organisasi. Strategi krisis yang digambarkan dengan jelas, dipahami seluruh bagian organisasi, menandakan pentingnya bergerak melampaui rencana rutinitas. Program tanggap krisis yang baik, akan menghindarkan organisasi dari membuang waktu dan sumber daya untuk mencari tahu siapa yang seharusnya melakukan apa, terutama pada awal-awal krisis, saat setiap momentum berharga. Program tanggap krisis ini harus menjadi bagian integral dari visi dan tujuan organisasi.

Rekomendasi PwC lainnya adalah, organisasi perlu lebih fokus pada peningkatan berkelanjutan dan membangun manajemen dan program ketahanan organisasi secara terintegrasi. Salah satu upaya penting adalah, secara kontinyu lakukan peninjauan dan perbaikan terhadap setiap respons organisasi secara bekelanjutan. Hubungkan antara hasil dan evaluasi, kemudian sesuaikan dengan keputusan dan tindakan, sehingga 
organisasi menjadi lebih kuat terhadap krisis dari waktu ke waktu. Dengan demikian, organisasi akan menjadi lebih siap untuk apa pun yang mungkin terjadi di kemudian hari.

Kesimpulan penting kedua $P w C^{\prime} s$ Global Crisis Survey 2021 adalah, semakin tidak relevannya segregasi antarbagian organisasi. Dalam dunia bisnis, dikenal istilah mentalitas silo (silo mentality). Istilah bisnis ini sering diperbincangkan oleh pelaku bisnis sejak 30 tahun terakhir (wartaekonomi.co.id, 20/2/2019). Mentalitas silo adalah sikap yang kerap ditemui di beberapa organisasi atau perusahaan. Silo itu merupakan sikap di dalam departemen perusahaan yang enggan berbagi informasi atau pengetahuan dengan individu lain dalam organisasi yang sama (Investopedia, 20/2/2019).

Egosektoral, sebutan lain mentalitas silo, semakin tidak relevan pada masa yang penuh dengan krisis dan gangguan seperti pandemi saat ini. Respon terintegrasi sangat penting untuk bisa melaksanakan program manajemen krisis yang efektif dan sukses dalam membangun ketahanan organisasi.

Sebelum pandemi Covid-19 menjungkirbalikkan keajekan pola hidup di seluruh dunia, banyak perusahaan membahas perencanaan ketahanan terhadap krisis sebagai latihan "di atas kertas." Dokumen-dokumen perencanaan tertulis itu perlu diperiksa. Pendekatan "di atas kertas" itu mengekspos banyak bisnis pada risiko yang seharusnya dapat dihindari. Seperti, ketika dihadapkan pada kerusakan akibat pandemi Covid-19. Terstruktur dalam mentalitas silo (terpisah-pisah), kompetensi ketahanan dan tim yang terpisah-pisah, rentan, serta tidak dilatih dan diperlengkapi untuk mengoordinasikan taktik, alat, dan teknologi yang diperlukan untuk respons yang efektif, menjadi isu yang harus semakin diperhatikan oleh para pemimpin bisnis.
Tujuh dari sepuluh pemimpin organisasi melaporkan bahwa mereka berencana meningkatkan investasi dalam membangun ketahanan organisasi. Lebih tinggi lagi di kalangan para manejer risiko, tren itu menjadi sembilan dari sepuluh organisasi. Hanya $23 \%$ responden merasa fungsi manajemen krisis mereka telah terintegrasi dengan baik.

Di antara responden yang mengatakan bahwa mereka terkena dampak negatif dari pandemi Covid-19, atau berada dalam posisi yang lebih buruk secara finansial, manajemen krisis, kelangsungan bisnis, dan perencanaan darurat, menempatkan urutan teratas untuk prioritas strategi ketahanan. Para pemimpin bisnis yang melaporkan berada di posisi yang lebih baik secara finansial, secara signifikan lebih cenderung mengatakan bahwa fungsi ketahanan organisasi mereka sudah relatif terintegrasi dengan baik. Komunikasi dan kolaborasi yang efektif tidak cukup hanya dinyatakan, melainkan harus dibangun, dilatih, dan dipraktikkan. Mendobrak silo memang sulit, tetapi itu sangat bermanfaat bagi kelangsungan dan ketahanan organisasi. Langkah ketahanan organisasi perlu diperiksa secara berkelanjutan, untuk membangun ketahanan yang holistik.

Ketahanan organisasi sangat penting, tidak hanya untuk berhasil, tetapi juga untuk bertahan hidup. Di tengah pergolakan pandemi selama 2020, fokus baru pada ketahanan organisasi mulai terbentuk di banyak organisasi. Menghadapi gangguan yang tidak dapat diprediksi, para pemimpin bisnis menyadari bahwa fondasi ketahanan yang dibangun sangat menentukan kelanjutan bisnis apakah akan runtuh, goyah, atau terus bertumbuh. Bahkan, ini berlaku untuk masa krisis maupun saat normal. Semakin tumbuh kesadaran tentang pentingnya evolusi ketahanan organisasi, maka semakin baik upaya dan kesadaran dalam membangun kesiapan untuk mengambil tindakan pencegahan terhadap ancaman krisis pada masa depan. 
Ketahanan individu dan organisasi akan muncul saat individu atau organisasi menghadapi tantangan yang belum pernah terjadi sebelumnya. Seperti saat pandemi saat ini pekerjaan dan sekolah jarak jauh, isolasi dan pembatasan mobilitas, serta penyesuaian lain, yang ditimbulkan pandemi. Kemampuan untuk beradaptasi, untuk mengelola perubahan mendasar dalam cara kita hidup dan bekerja, merupakan inti dari ketahanan individu dan organisasi.

Organisasi yang tetap baik saat ini, secara signifikan lebih mungkin untuk mengatakan bahwa mereka telah memberikan perhatian yang substansial terhadap isu ketahanan. Arti ketahanan, secara sederhana, adalah kemampuan untuk bangkit kembali dari krisis dan gangguan. Selain untuk bertahan, itu juga tentang bersiap untuk mengaktifkan dan mengamankan kemungkinan baru. Ketika periode pasca pandemi mulai terbentuk dalam beberapa bulan mendatang, organisasi memiliki kesempatan untuk memikirkan kembali peluang untuk masa depan. Ada optimisme, dari data Survei Krisis Global 2021, yang mengungkapkan bahwa tiga dari empat perusahaan yakin bahwa mereka bisa berhasil mengintegrasikan apa yang telah mereka pelajari melalui krisis pandemi ini dan memperkuat ketahanan organisasi mereka untuk selanjutnya.

\section{Sektor Publik}

Organisasi sektor publik merupakan bagian dari sistem perekonomian negara yang bertujuan untuk melayani kepentingan publik guna mewujudkan kesejahteraan masyarakat. Contoh sektor publik adalah institusi pemerintahan, partai politik, lembaga pendidikan, dan fasilitas pelayanan kesehatan. Fokus utama organisasi sektor publik ini adalah pelayanan kepada masyarakat. Akuntabilitas kinerja menjadi faktor penting dalam mempertahankan/menjaga $\begin{array}{lcr}\text { kepercayaan } & \text { masyarakat } & \text { terhadap } \\ \text { organisasi } & \text { sektor } & \text { publik }\end{array}$ (https://www.pengadaan.web.id/2019/12/s ektor-publik.html).

Sektor publik identik dengan sektor negara, usaha-usaha negara, dan organisasi nirlaba negara. Dengan kata lain, organisasi sektor publik adalah pemerintah dan unitunit organisasi di dalamnya, yaitu unit-unit kerja yang dikelola pemerintah dan berkaitan dengan hajat hidup orang banyak (publik) atau pelayanan masyarakat, seperti kesehatan, pendidikan, keamanan, dan ketertiban.

Pengertian sektor publik, secara sederhana, adalah sektor pelayanan yang menyediakan barang/jasa bagi masyarakat umum dengan sumber daya yang berasal dari pajak dan penerimaan negara lainnya, di mana kegiatannya banyak diatur dengan ketentuan dan peraturan (IG Agung Rai, 2008:3).

Broadbent dan Guthrie (1992) dalam Agung Rai (2008:4), mengidentifikasi sektor publik dari segi kegiatan (aktivitas), adalah seluruh kegiatan yang dibiayai oleh pemerintah, baik dari hasil pungutan pajak, maupun penerimaan negara lainnya, termasuk yang bersumber dari utang. Jenis kegiatan yang dilakukan adalah penyediaan pelayanan masyarakat. Dilihat dari segi kepemilikan, sektor publik adalah segala sesuatu yang dimiliki oleh umum atau masyarakat, bukan oleh pemegang saham atau kelompok orang.

Dari penjelasan di atas dapat disimpulkan bahwa definisi sektor publik masih sangat beragam, karena dipengaruhi oleh sistem pemerintahan, situasi politik, dan cara pengelolaan pada sektor publik. Sebagai contoh, di Indonesia pemahaman dan penghayatan makna dari Pasal 33 ayat (2) UUD 1945 yang berbunyi: "Cabangcabang produksi yang penting bagi negara dan yang menguasai hajat hidup orag 
banyak dikuasai oleh negara" telah berubah dari satu orde ke orde pemerintahan lain.

Hal yang menyebabkan perubahan makna dan konsep sektor publik adalah adanya privatisasi sektor publik. Pada masa pemerintahan orde lama, semua cabang produksi yang menguasai hajat hidup orang banyak dikuasai dan dilaksanakan oleh negara. Namun, seiring dengan perkembangan sistem ekonomi, maka pemerintah mulai melakukan privatisasi atas sektor produksi tersebut karena alasan efisiensi dan pengumpulan dana privat untuk pembangunan (IG Agung Rai, 2008:5).

Barang publik produk sektor publik berdasarkan sudut pandang ekonomi adalah barang dan jasa yang diadakan oleh sektor publik (pemerintah) untuk keperluan masyarakat. Barang dan jasa ini harus diproduksi karena secara alamiah barang atau jasa tersebut harus disediakan oleh negara dan/atau adanya kegagalan pasar (market failure) sehingga sektor privat tidak mau atau tidak mampu memproduksi barang publik tersebut. Terdapat dua sifat utama barang publik, yaitu nonexcludability dan nonrivalness in consumtion. Nonexcludability berarti bahwa bahwa barang tersebut dapat dinikmati oleh semua orang tanpa mengorbankan kenikmatan orang lain. Sedangkan nonrivalness in consumtion berarti bahwa dalam menggunakan barang tersebut orang tidak perlu bersaing untuk mendapatkannya.

Dapat dinikmati oleh semua orang mengandung arti bahwa tidak ada seorang pun yang dapat dikecualikan dari pemanfaatan barang publik. Manfaat barang publik menyebar ke seluruh masyarakat dan tidak dapat dipilah-pilah, terlepas dari apakah individu menginginkannya atau tidak. Sebagai contoh adalah pertahanan keamanan yang dapat dirasakan oleh semua warga negara. Pertahanan keamanan tidak dapat "dibungkus" dan "dibagikan" secara tersendiri kepada masyarakat atau dijual dengan harga tertentu.

Selain itu, karena sifatnya yang tidak ada persaingan dalam konsumsi, maka satu orang dapat meningkatkan kepuasannya terhadap barang publik, tanpa mengurangi kepuasan orang lain. Dengan kata lain, biaya marginal dari setiap tambahan konsumsi adalah nol. Contoh dari barang publik adalah mercusuar, yang berfungsi memberikan arah dan penerangan bagi kapal-kapal lain. Manfaat yang diperoleh satu kapal tidak akan mengurangi manfaat bagi kapal lainnya.

Anggaran sektor publik merupakan instrumen perencanaan dan pengendalian yang sangat penting, sekaligus merupakan blue print tentang rencana program dan kegiatan yang akan dilaksanakan oleh organisasi sektor publik. Sedangkan sektor privat, anggaran bersifat fleksibel, disesuaikan dengan kondisi dan perkembangan lingkungan dan ekonomi yang terjadi.

\section{Kapasitas Organisasi Publik}

Organisasi dirancang sedemikian rupa agar bertahan dari waktu ke waktu, untuk secara rutin dan berkelanjutan menjalankan kegiatan dan operasionalnya. Organisasi juga diharapkan dapat membangun stabilitas operasionalnya, terlepas dari kebutuhan perubahan personel yang menjadi penggeraknya. Kemampuan bertahan suatu organisasi tidak serta merta menunjukkan efektivitas kinerjanya, sebab organisasi dapat bertahan meski dianggap oleh banyak orang tidak kompeten (Meyer dan Zucker, 1989). Daya tahan organisasi juga tidak identik dengan kekakuan. Beberapa organisasi memang dirancang untuk menggabungkan fleksibilitas yang tinggi, dengan pemeliharaan dalam konteks kemampuan mengubah kombinasi personel, struktur, dan bahkan tujuannya (Scott, 2003). 
Organisasi harus mampu meyesuaikan perilakunya dalam merespon dinamika lingkungan untuk dapat bertahan. Fokus organisasi dalam meningkatkan kemampuan bertahan pada lingkungan yang selalu berubah, memerlukan dukungan sejumlah faktor. Staats et al. (2004) menjelaskan setidaknya ada tiga faktor yang harus dimiliki organisasi dalam penyesuaian dengan dinamika lingkungan tersebut, yaitu informasi, umpan balik terhadap kinerja, serta lingkungan sosial yang mendukung.

Organisasi cenderung menjadi wahana untuk melakukan hal yang sama dengan cara yang sama secara berulang. Di dalamnya, akan terlihat berbagai mekanisme kontrol, termasuk formalisasi aturan, struktur otoritas, standar kerja rutin, budaya kerja, dan sebagainya. Faktor tersebut dirancang untuk meningkatkan keandalan kegiatan dan pekerjaan yang dilakukan. Dalam situasi yang beragam dan lingkungan yang berubah, kemampuan untuk memproduksi (barang dan layanan) melalui berbagai jenis kegiatan, mencerminkan keunggulan yang berhubungan dengan tingkat keandalan suatu organisasi (Scott, 2003).

Organisasi dengan keandalan yang tinggi, ditandai sikap menerima dan cepat menyesuaikan dengan kegagalan, kepekaan terhadap tuntutan, komitmen terhadap ketahanan, dan di bawah struktur tertentu (Weick et al., 1999). Thompson (2003) mengembangkan konsep Parsons (1960), yang membedakan organisasi atas tiga tingkatan: Pertama, tingkat teknis, yaitu bagian dari organisasi yang memiliki kapasitas menjalankan fungsi dalam menghasilkan produk yang mengubah input menjadi output. Kedua, level manajerial, yaitu bagian dari organisasi yang memiliki kapasitas dan tanggung jawab untuk merancang dan mengendalikan sistem yang menghasilkan produk untuk pengadaan input dan menghasilkan output, serta untuk mengamankan dan mengalokasikan personel pada setiap unit dan fungsi. Ketiga, tingkat kelembagaan, merupakan kapasitas organisasi yang menghubungkan organisasi dengan lingkungan yang lebih luas, menentukan domainnya, menetapkan batas-batasnya, dan mengamankan legitimasinya.

Grindle dan Hilderbrand (1995) mendefinisikan, membangun kapasitas (capacity building) organisasi sebagai upaya untuk peningkatkan kemampuan organisasi publik dalam mencapai tujuan tertentu baik secara mandiri maupun berkerja sama dengan organisasi lainnya. Sementara, Horton et al. (2003) menjelaskan bahwa pengembangan kapasitas merupakan kemampuan untuk menampilkan fungsi dasar, yakni pencapaian tujuan, pembelajaran, dan penyelesaian masalah.

Pendapat beberapa ahli menyebutkan, pengembangan kapasitas secara umum disepakati pada wilayah individu dan organisasi. Dimensi individu dan organisasi ini berinteraksi dengan lingkungan dalam proses mengembangkan kapasitas tersebut, di mana sistem dan komunitas merupakan lingkungan organisasi dan individu di dalam suatu organisasi. Pengembangan kapasitas dalam konteks organisasi berkaitan dengan upaya meningkatkan kemampuan suatu organisasi publik, termasuk kemampuan dalam penyelenggaraan layanan sektor publik. Pengembangan kapasitas organisasi merupakan strategi penting, agar suatu organisasi pelayanan publik memiliki kemampuan merancang strategi agar organisasi mencapai tujuannya dengan desain organisasi yang menjamin efisiensi, efektivitas, responsivitas, dan berkelanjutan.

Organisasi dirancang sedemikian rupa untuk bertahan dari waktu ke waktu, secara rutin dan terus menerus melakukan serangkaian kegiatan tertentu, untuk mencapai tujuan tertentu. Organisasi 
diharapkan dapat mencapai stabilitas dari waktu ke waktu. Kemampuan bertahan itu tidak serta-merta mengindikasikan efektivitas organisasi dalam menjalankan peran dan fungsinya, karena organisasi dapat bertahan meski dianggap oleh banyak orang tidak kompeten (Meyer dan Zucker, 1989). Daya tahan organisasi tidak selalu identik dengan kekakuan. Beberapa bentuk baru dari organisasi dirancang untuk menggabungkan fleksibilitas dengan pemeliharaan dalam konteks kapasitas dengan mengubah kombinasi personel, struktur, dan bahkan tujuan (Scott, 2003).

Organisasi harus mampu meyesuaikan diri dalam merespon lingkungannya untuk dapat bertahan. Fokus organisasi dalam meningkatkan kemampuan bertahan pada lingkungan yang terus berubah harus didukung sejumlah faktor penting. Staats et al (2004), misalnya, menjelaskan bahwa ada tiga faktor yang harus dimiliki dalam penyesuaian dengan lingkungan, yaitu informasi, umpan balik terhadap kinerja, dan lingkungan sosial yang mendukung.

Peraturan Presiden Nomor 59 Tahun 2012 tentang Kerangka Nasional Pengembangan Kapasitas Pemerintah Daerah menjelaskan, kapasitas pemerintahan daerah adalah kemampuan pemerintahan daerah untuk merencanakan, mengorganisasikan,

mengawasi dan mengevaluasi penyelenggaraan urusan pemerintahan yang dilaksanakan oleh pemerintahan daerah berdasarkan asas desentralisasi dan tugas pembantuan secara efektif, efisien, dan berkesinambungan. Pengembangan kapasitas daerah diartikan sebagai upaya yang dilakukan oleh pemerintah dan pemerintah daerah untuk meningkatkan kapasitas pemerintahan daerah, yang kemudian dituangkan dalam Rencana Aksi Pengembangan Kapasitas Pemerintahan, sebagai dokumen perencanaan pengembangan kapasitas provinsi, kabupaten/kota, yang memuat program dan pengembangan kapasitas pemerintahan daerah untuk setiap periode 5 (lima) tahun.

Dalam Peraturan Presiden tersebut dijelaskan ruang lingkup pengembangan kapasitas pemerintahan daerah meliputi: (a) Pengembangan kapasitas kebijakan; (b) Pengembangan kapasitas kelembagaan; dan (c) Pengembangan kapasitas sumber daya manusia. Pengembangan kapasitas kebijakan meliputi penyusunan dan penetapan kebijakan daerah berupa peraturan daerah dan/atau peraturan kepala daerah yang dilakukan berdasarkan prinsipprinsip tata kelola pemerintahan yang baik (good governance) dan sesuai dengan peraturan perundang-undangan yang ada. Selain itu, evaluasi implementasi kebijakan daerah untuk menilai efektivitas pelaksanaannya; serta membangun komitmen seluruh penyelenggara pemerintahan daerah untuk melaksanakan kebijakan daerah yang telah ditetapkan.

Pengembangan kapasitas kelembagaan meliputi peningkatan kapasitas struktur organisasi yang efektif, efisien, rasional, dan proporsional; peningkatan kapasitas tata laksana penyelenggaraan tugas pokok dan fungsi setiap unit kerja pemerintahan daerah; pelembagaan budaya kerja organisasi yang produktif dan positif berdasarkan nilai-nilai luhur budaya bangsa; peningkatan kapasitas anggaran untuk mendukung peningkatan kualitas dan kuantitas pembangunan dan penyelenggaraan pemerintahan daerah. Selain itu, peningkatan kapasitas sarana dan prasarana kerja sesuai dengan kebutuhan dan tuntutan tugas; dan penerapan standar prosedur operasi (standard operating procedure) dalam penyelenggaraan pemerintahan daerah dan pelayanan umum.

Sedangkan pengembangan kapasitas sumber daya manusia meliputi peningkatan pengetahuan dan wawasan, keterampilan, dan keahlian, serta pembentukan sikap dan perilaku kerja penyelenggara pemerintahan daerah. Pengembangan kapasitas sumber 
daya manusia sebagaimana dilakukan melalui penyelenggaraan pendidikan formal, pelatihan dan kursus, seminar, magang, pendampingan, pendidikan kepribadian, dan pendidikan dalam jabatan.

Organisasi merupakan sarana yang dapat melakukan hal yang sama dengan cara yang sama secara berulang. Dalam organisasi, akan terlihat berbagai mekanisme kontrol digunakan, termasuk formalisasi, struktur otoritas, menguraikan aturan dan rutinitas, serta budaya yang memengaruhinya. Faktor tersebut dirancang untuk meningkatkan keandalan kegiatan pekerjaan yang dilakukan. Kemampuan dalam memproduksi barang dan layanan berkualitas adalah keuntungan besar yang berhubungan dengan keandalan organisasi (Scott, 2003).

Keandalan organisasi akan dapat dicapai melalui pengembangan rutinitas yang terstandar (Hannan dan Freeman, 1984). Bahkan, gagasan pengulangan atau reproduksibilitas tindakan atau pola aktivitas adalah defenisi dasar dari keandalan. Dari waktu ke waktu, rutinitas dan keandalan telah menjadi identik satu sama lain, dan juga dapat dikaitkan sebagai faktor pendukung kecenderungan yang bersifat positif atau dapat mengurangi kemampuan adaptif (Hannan dan Freeman, 1984).

Organisasi yang memiliki keandalan yang tinggi, ditandai dengan sikap menerima dan menyesuaikan dengan kegagalan, keengganan untuk menyederhanakan interpretasi, kepekaan terhadap dinamika dan kegiatan, komitmen terhadap ketahanan (konsisten), dan di bawah struktur tertentu (Weick et al., 1999). Proses ini mengurangi inersia yang memungkinkan terjadinya kegagalan dan dampak negatif yang lebih luas bagi organisasi.

Thompson (2003) mengembangkan konsep yang dibuat oleh Parsons (1960), yang membedakan organisasi atas tiga tingkatan. Pertama ialah tingkat teknis, yakni bagian dari organisasi yang memiliki kapasitas menjalankan fungsi dalam menghasilkan barang atau jasa yang mengubah input menjadi output.

Kedua adalah level manajerial, yaitu bagian dari organisasi yang memiliki kapasitas dan tanggung jawab untuk merancang dan mengendalikan sistem yang menghasilkan barang atau jasa untuk pengadaan input dan membuat output, dan untuk mengamankan dan mengalokasikan personil untuk setiap unit dan fungsi.

Ketiga, tingkat kelembagaan, yang merupakan kapasitas dari organisasi yang menghubungkan organisasi dengan lingkungan yang lebih luas, menentukan domainnya, menetapkan batas-batasnya, dan mengamankan legitimasinya. Lebih lanjut, Thompson (2003) menyatakan bahwa masing-masing dari tiga perspektif teori cocok ke tingkat yang berbeda dari organisasi: perspektif sistem rasional untuk tingkat teknis, perspektif system alamiah untuk level manajerial, dan perspektif system terbuka untuk tingkat institusional (Scott, 2003; Thompson, 2003).

Grindle dan Hilderbrand, (1995) mendefenisikan capacity building sebagai improvements in ability of public organizations, either single or cooperation with other organizations, to perform aproriate tasks. Dengan kata lain, Capacity building tersebut merupakan peningkatkan kemampuan organisasi publik dalam mencapai tujuan tertentu baik secara mandiri maupun berkerja sama dengan organisasi lainnya. Horton et al. (2003) yang menjelaskan bahwa pengembangan kapasitas merupakan "an ongoing process to increase the ability of organization to carry out its functions and acheive its objectives, and to learn and solve problems". Konsep ini menjelaskan pengembangan kapasitas sebagai kemampuan untuk menampilkan fungsi 
dasar, yakni pencapaian tujuan, pembelajaran dan penyelesaian masalah.

Pendapat ini hampir sama dengan yang dikemukakan oleh Milen (2000) yang melihat capacity building sebagai continuing process of strengthening of ability to perform core function, solve problem, define and achieve objective and understand and deal with development need.

Sedangkan OECD (2008) menjelaskan bahwa pengembangan kapasitas ialah "process whereby people, organizations and society as a whole unleash, strengthen, create, adapt and maintain capacity over time." Maknanya ialah pengembangan kapasitas sebagai sebuah proses keberlanjutan kapasitas secara terus menerus. Pendapat ini lebih menekankan orientasi pengembangan kapasitas sebagai penguatan berbagai kemampuan dalam berbuat.

Definisi lain yang senada dikemukakan oleh Brown et al. (2001) capacity building sebagai suatu proses yang dapat meningkatkan kemampuan seseorang, kelompok, suatu organisasi atau suatu sistem dalam upaya mencapai tujuan atau menghasilkan yang lebih baik. Morison (2001) melihat capacity building sebagai suatu proses atau serangkaian aktivitas untuk melakukan sesuatu perubahan baik pada level di dalam individu, kelompok, organisasi dan sistem dalam rangka untuk memperkuat kemampuan penyesuaian individu dan organisasi sehingga dapat tanggap terhadap perubahan lingkungan yang ada. Kedua pendapat di atas lebih menekankan pada tingkatan dimana pengembangan kapasitas itu berada dan orientasi pengembangan kapasitas yang dilakukan ada pada proses.

Dari beberapa pendapat ahli, kajian pengembangan kapasitas secara umum disepakati pada wilayah individu dan organisasi, walaupun pada dimensi yang lebih luas ada sedikit perbedaan. Dalam konteks sistem (Brown, 2001; Morison, 2001, Araya-Quesada et al. (2010), komunitas (Banyan, 2007), lingkungan (OECD, 2008), institusi (Grindle, 1997; Horton et al., 2003) memiliki orientasi yang sama, yakni bagaimana dimensi individu dan organisasi dapat berinteraksi dengan lingkungan dalam mengembangkan kapasitasnya, dan sistem serta komunitas merupakan lingkungan organisasi dan individu di dalam organisasi tersebut. Bahkan pada dimensi reformasi institusi (Grindle, 1997) yang menurut Dill (2000) memiliki fokus pada institusi dan sistem sebagai struktur yang bersifat makro. Konsep Grindle tersebut tidak berbeda dengan yang disebutkan Harton et al (2003) dengan konsep institusi nasional yang mempengaruhi level mikro (individu dan kelompok) ataupin level meso (organisasi).

Pada level mikro yang fokus pada individu dan kelompok sebagai kumpulan individu, pengembangan kapasitas fokus pada penyediaan sumber daya profesional dan teknikal (Grindle, 1997; Dill, 2000; Horton et al., 2003). Pendapat ini dikuatkan oleh Klingner dan Nalbadian (2003:49) yang menjelaskan bahwa professionalisasi dapat memperkuat kapasitas organisasi publik dengan ketersediaan keterampilan yang jelas, jalur pendidikan dan pelatihan yang mendukung, dan standar etika. Pada level individu, keterampilan, pendidikan dan pelatihan, dan standar etika menjadi kreteria penting. Indikator-indikator professional tersebut berkaitan dengan kinerja individu dan efektivitas kinerja organisasi (Behrman, 2006).

Pada level meso, yakni organisasi, fokus pengembangan kapasitas pada sistem manajemen yang berusaha meningkatkan kinerja pada tugas dan fungsi yang spesifik (Grindle, 1997; Dill, 2000; Horton et al., 2003). Di sisi lain, Rainey (2003) fokus pada pencapaian efektivitas organisasi melalui tiga kategori yaitu misi (orientasi) publik, kepemimpinan, serta desain tugas atau lingkungan pekerjaan. Sedangkan 
pada level pengembangan kapasitas yang lebih luas yakni Makro terdiri dari beberapa pendapat. Sebagai contoh adalah level reformasi institusi atau institusi nasional yang memiliki fokus pada kajian institusi atau sistem yang ada (Grindle, 1997; Dill, 2000; Horton et al., 2003). Selain itu menurut Sumpeno (2002), hasil yang diharapkan dengan adanya penguatan kapasitas adalah penguatan individu, organisasi dan masyarakat, terbentuknya model pengembangan kapasitas dan program, dan terbangunnya sinergisitas pelaku dan kelembagaan.

Pengembangan kapasitas dalam konteks organisasi berkaitan dengan upaya meningkatkan kemampuan suatu organisasi publik (Indrawijaya dan Pranoto, 2011). Lebih jauh, pengembangan kapasitas organisasi merupakan strategi penting agar suatu organisasi pelayanan publik memiliki kemampuan dalam menyusun rencana strategis ditujukan agar organisasi mencapai tujuannya dengan jelas dan mampu mendesain organisasi untuk menjamin efisiensi, efektivitas, responsivitas. Pada level institusi, pengembangan kapasitas diarahkan kemampuan menciptakan aturan main yang mampu merespon dan memformulasikan kebijakan dengan memperhatikan nilai efisiensi, efektivitas, responsivitas, keadilan, partisipasi, dan keberlanjutan.

\section{Pemerintahan Kolaboratif}

Dalam kondisi pandemi Covid-19, berbagai bentuk kependulian sosial muncul di tengah masyarakat (pse.litbang.pertanian.go.id). Semua komponen masyarakat hendaknya bersatu, tanpa melihat latar belakang golongan, suku, agama, profesi, apalagi sekadar afiliasi politik. Berbagai bentuk aksi kepedulian sosial, baik secara spontanitas maupun terencana, hadir memberikan bantuan bagi sesama yang terpapar virus korona. Baik di jalan-jalan maupun di rumah-rumah keluarga yang mengalami keterpurukan ekonomi karena pemutusan hubungan kerja, atau karena terhenti aktivitas usahanya. Aksi tersebut dilakukan oleh berbagai elemen masyarakat, mulai dari organisasi formal, kelompok informal, profesi tertentu, maupun yang bersifat individual. Gerakan swadaya ini akan semakin memperkuat daya tahan masyarakat menghadapi wabah yang belum juga usai.

Pada saat yang sama, pemerintah juga terus melakukan berbagai program dan aksi untuk mengatasi penyebaran wabah, dan juga menggulirkan program bantuan bagi masyarakat terdampak. Namun, tentu saja sumber daya dan kapasitas yang dimiliki pemerintah relatif terbatas, dengan jumlah penduduk yang besar dan cakupan wilayah yang luas. Oleh karena itu, diperlukan kemampuan membangun kerja sama yang lebih baik dan intensif, baik antara pemerintah dengan elemen masyarakat, maupun sesama komponen bangsa. Kerja sama atau kolaborasi tersebut penting dibangun mulai dari perumusan sampai implementasi kebijakan publik atau program-program yang akan digulirkan oleh pemerintah.

Tata kelola pemerintahan kolaboratif (collaborative governance), semakin relevan saat ini. Bersamaan meningkatnya konektivitas sosial-ekonomi yang difasilitasi hadirnya TIK dan internet. Ansell dan Grash (2007: 545) mendefinisikannya: "Collaborative governance is therefore a type of governance in which public and private actor work collectively in distinctive way, using particular processes, to establish laws and rules for the provision of public goods."

Konsep ini menyatakan pentingnya kondisi di mana aktor publik dan aktor privat (swasta) bekerja sama dengan cara dan proses tertentu, yang nantinya akan menghasilkan regulasi dan kebijakan yang tepat bagi publik. Konsep ini menjelaskan bahwa dalam penyelenggaraan 
pemerintahan, unsur pemerintah, unsur masyarakat, juga swasta (organisasi bisnis atau perusahaan) bukanlah suatu yang terpisah dan sendiri-sendiri, melainkan terkoneksi dan bekerja bersama untuk kepentingan kolektif.

Kolaborasi dipahami sebagai kerjasama antaraktor, antarorganisasi, atau antarinstitusi dalam rangka pencapain tujuan yang tidak bisa dicapai secara masing-masing. Istilah kerjasama dan kolaborasi acap masih digunakan secara bergantian. Secara definisi, para ahli mendefinisikan collaborative governance dalam beberpa makna, tetapi ide utamanya sama, yaitu kolaborasi antara sektor publik dan nonpublik (privat) dalam penyelenggaraan tata kelola pemerintahan atau governance. Dalam definisi Ansell dan Gash (2007:546), collaborative governance adalah serangkain pengaturan di mana satu atau lebih lembaga publik melibatkan secara langsung stakeholder nonstate dalam proses pembuatan kebijakan secara formal, berorientasi konsensus, dan dialogis yang bertujuan untuk membuat atau mengimplementasikan kebijakan publik atau mengatur program atau aset.

Pendapat lain tentang collaborative governance dikemukakan Agranoff dan McGuire (dalam Chang, 2009: 76-77) yang menyatakan bahwa, secara khusus, collaborative gvernance telah menempatkan banyak penekanan pada kolaborasi horizontal sukarela, dan hubungan horizontal antara partisipan multi-sektoral, karena tuntutan dari klien sering melampaui kapasitas dan peran organisasi publik tunggal. Maka, konsep ini membutuhkan interaksi berbagai organisasi yang terkait dan terlibat dalam kegiatan publik. Kolaborasi diperlukan, sehingga memungkinkan governance menjadi terstruktur dan efektif dalam merespon meningkatnya permintaan yang timbul dari interaksi lintas pemerintah, organisasi, dan batas sektoral.
Berdasarkan pada pendefinisian tersebut, collaborative governance menemukan benang merahnya. Meski, ada penekanan yang berbeda. Ansell dan Gash melihat kolaborasi penyelenggaraan pemerintah lebih pada konteks perumusan dan impletasi kebijakan publik atau program dari lembaga pemerintah. Sedangkan gagasan Agranoff dan McGuire menekankan kolaborasi penyelenggaraan pemerintahan pada lingkup yang lebih umum dan menitik beratkan pada aspek sukarela dalam praktiknya. Dengan kesukarelaan itu, diharapkan setiap aktor yang terlibat dalam kolaborasi bekerja secara optimal untuk tercapainya tujuan bersama, sehingga program atau kebijakan yang yang dilaksanakan akan terlaksana lebih efektif karena melibatkan relasi oganisasi atau institusi.

Dalam dunia industri, kata collaboration digunakan sejak abad ke-19, pada saat industrialisasi berkembang dan munculnya organisasi yang lebih kompleks, dengan pembagian kerja dan tugas yang semakin beragam. Kolaborasi yang efektif diupayakan untuk pencapaian sasaran klien atau kepuasan konsumen, meningkatkan koneksi antarorganisasi, serta pengembangan organisasi. O'Leary, Gazley, McGuire and Bingham (dalam Junadi, 2015:14) menyebutkan, tiga dimensi yang berbeda dalam kolaborasi antarorganisasi, yang merefleksikan perbedaan sasaran organisasi: pertama, mendapatkan sumber daya dan meningkatkan pelayanan; kedua, memperbesar manfaat kolektif dan mengembangkan potensi organisasi; ketiga, meningkatkan keuntunga organisasi secara langsung.

Junaidi (2015: 8) menyebutkan, collaborative governance tidak muncul tiba-tiba. Ia lahir dari inisiatif berbagai pihak yang tergerak melakukan kerjasama dan koordinasi untuk menyelesaikan masalah. Kolaborasi penyelenggaraan pemerintahan hadir merespon kegagalan 
implementasi dan tingginya biaya akibat politisasi terhadap regulasi (Ansell dan Gash, 2007: 54). Dorongan kolaborasi juga muncul seiring dengan perkembangan ilmu pengetahuan dan tuntutan peningkatan kapasitas institusi atau organisasi, serta kesadaran akan keterbatasan kemampuan lembaga untuk melakukan program atau kegiatannya secara sendiri. Kolaborasi juga muncul karena keterbatasan anggaran dari suatu lembaga, sehingga melalui kolaborasi, sumber anggaran tidak hanya dari satu lembaga, tetapi lembaga lain yang terlibat dalam kolaborasi.

Kolaborasi semakin relevan seiring perkembangan ilmu pengetahuan dan teknologi, yang mendorong terjadinya transformasi tata kelola pemerintahan. Keterbukaan informasi dan kecanggihan teknologi informasi-komunikasi memperkuat kesadaran akan pentingnya keterlibatan publik dalam penyelenggaraan pemerintah. Seperti halnya dalam dunia industri pada era Revolui Industri 4.0, di mana kemampuan bersaing tidak hanya ditentukan kapasitas satu institusi secara mandiri, melainkan kemampuannya dalam membangun kolaborasi. Kolaborasi juga menjadi alternatif dalam mengembangkan keterlibatan kelompok kepentingan. Kompleksitas yang muncul dalam perkembangannya, menciptakan kondisi saling ketergantungan antarinstitusi, dan dengan demikian meningkat pula kebutuhan untuk berkolaborasi.

Selanjutnya, penjelasan lainnya yang lebih spesifik dikemukan Ansell dan Grash, bahwa collaborative governance muncul secara adaptif, atau diciptakan secara sadar, karena alasan-alasan dan pentingnya konsep ini dilakukan, yaitu: (1) kompleksitas dan saling ketergantungan antar institusi; (2) adanya konflik antarkelompok kepentingan yang bersifat laten dan sulit diredam; (3) upaya mencarai cara-cara baru untuk mencapai legitimasi politik; (4) kegagalan implementasi kebijakan; (5) ketidakmampuan kelompok- kelompok, terutama karena pemisahan rezim-rezim kekuasaan untuk menggunakan arena-arena institusi lainnya untuk menghambat keputusan; (6) mobilisasi kelompok kepentingan; serta (7) tingginya biaya dan politisasi regulasi (Junaedi, 2015:10).

Pendapat di atas menyatakan bahwa kolaborasi dilakukan karena ada kompleksitas dan saling ketergantungan antarinstitusi. Kolaborasi juga munucul akibat beragamnya kepentingan antarkelompok, sehingga memunculkan kebutuhan untuk suatu kolaborasi. Kolaborasi dapat menjadi solusi buruknya implementasi program atau kegiatan yang dilakukan oleh satu lembaga secara independen, karena keterbatasan lembaga tersebut. Kolaborasi juga bisa menjadi solusi untuk mengatasi tingginya biaya dari suatu program atau kegiatan.

\section{HASIL DAN PEMBAHASAN}

\section{Pandemi dan Sektor Publik}

Pada 16 Maret 2020, Gubernur Lampung Arinal Djunaidi mengeluarkan surat imbauan, dengan Nomor 440/1022/06/2020, perihal antisipasi dan kesiap-siagaan menghadapi Covid-19 di daerah. Surat tersebut ditujukan kepada bupati, walikota, kepala instansi vertikal, rektor perguruan tinggi negeri dan swasta se-Provinsi Lampung, serta kepala organisasi pemerintah daerah di lingkup Pemerintah Provinsi Lampung. Isinya, antara lain, menginstruksikan pembentukan Gugus Tugas Penanganan Covid-19 di lingkungan kerja masing-masing. ASN juga dapat melaksanakan tugas kantor/kedinasan di rumah masing-masing (bukan libur), guna meminimalisir penyebaran Covid-19, terhitung 17-30 Maret 2020 (14 hari kalender).

Surat itu juga menyebut, pelaksanaan belajar-mengajar di semua jenjang dan jenis pendidikan di Provinsi Lampung, agar 
dilakukan di rumah peserta didik masingmasing. Juga, agar bupati, walikota, dan instansi terkait melakukan pengawasan ketersediaan pangan, demi terjaminnya pasokan pangan utama bagi masyarakat dengan harga terjangkau. Kebijakan work from home (WFH) bagi ASN kemudian diperpanjang hingga 4 Juni, sebagaimana diatur Surat Edaran Menteri PANRB, tertanggal 28 Mei 2020. Kementerian Pendidikan dan Kebudayaan juga membuat skenario belajar dari rumah (sekolah online) hingga akhir 2020. Pembelajaran jarak jauh (PJJ) itu pun masih berlangsung sampai Juni 2021, dan belum ada kepastian kapan pembelajaran tatap muka dapat mulai efektif dilaksanakan lagi.

Organ-organ pemerintah pusat dan daerah bergegas merespon Covid-19 yang belum terkendali, meski sudah 1,5 tahun lebih. Terkait anggaran, misalnya, pemerintah meratifikasi Peraturan Pemerintah Pengganti Undang-Undang (Perppu) Nomor 1 Tahun 2020 tentang Kebijakan Keuangan Negara dan Stabilitas Keuangan untuk Penanganan Pandemi Covid-19 dan/atau Dalam Rangka Menghadapi Ancaman yang Membahayakan Perekonomian Nasional dan/atau Stabilitas Sistem Keuangan. Dalam Perppu tersebut, diatur pelaksanaan APBN untuk penanganan pandemi, dan menghadapi ancaman yang membahayakan perekonomian nasional dan/atau stabilitas sistem keuangan. Meliputi kebijakan perpajakan, belanja negara termasuk keuangan daerah, serta pembiayaan. Kemudian keluar Instruksi Presiden (Inpres) Nomor 4 Tahun 2020 tentang Refocussing Kegiatan, Relokasi Anggaran, serta Pengadaan Barang dan Jasa dalam rangka Percepatan Penanganan Covid-19. Dalam Inpres tersebut, diatur langkah-langkah cepat, tepat, fokus, terpadu, dan sinergi antara kementerian/lembaga dan pemerintah daerah, untuk melakukan refocussing kegiatan, realokasi anggaran, serta pengadaan barang dan jasa, dalam rangka percepatan penanganan pandemi.
Pemerintah pusat dan daerah membentuk Gugus Tugas Percepatan Penanganan Covid-19. Dasarnya adalah Keputusan Presiden Nomor 7 Tahun 2020, kemudian diubah dengan Keputusan Presiden Nomor 9 Tahun 2020 tentang Perubahan Atas Keputusan Presiden Nomor 7 Tahun 2020 tentang Gugus Tugas Percepatan Penanganan Covid-19. Serangan virus corona ditetapkan oleh pemerintah sebagai jenis penyakit yang menimbulkan kedaruratan kesehatan masyarakat, dengan Keputusan Presiden Nomor 11 Tahun 2020 tentang Penetapan Kedaruratan Kesehatan Masyarakat Corona Virus Disease, yang memuat upaya penanggulangannya sesuai dengan ketentuan peraturan perundang-undangan.

Dari sisi aturan, pemerintah tanggap menyikapi pandemi, dengan menerbitkan sejumlah regulasi, mulai dari Perppu, peraturan pemerintah, keputusan presiden, instruksi presiden, peraturan menteri, keputusan menteri, surat edaran menteri, juga peraturan dan keputusan lembaga terkait, seperti dari Otoritas Jasa Keuangan (OJK), Gugus Tugas Percepatan Penanggulangan Covid-19, Badan Nasional Penanggulangan Bencana (BNPB), hingga Fatwa Majelis Ulama Indonesia (MUI) tentang Penyelenggaraan Ibadah dalam Situasi Terjadi Wabah Covid-19.

Organisasi yang mampu memetik buah manis dari krisis, pada umumnya mereka melakukan langkah strategis, yang membedakannya dengan organisasiorganisasi pada umumnya yang terpaksa merasakan dampak buruk pandemi. Organisasi tersebut mampu memperluas pendekatan terhadap risiko dan krisis, serta menerapkan strategi holistik-terintegrasi dalam membangun ketahanan organisasi. Mereka mampu melihat secara seksama respon krisis, dan memperbaiki secara terus-menerus. Mereka mampu menerjemahkan wawasan (data) dan pelajaran yang diperoleh dari krisis ke 
dalam strategi organisasi dalam jangka panjang. Secara aktif mereka juga terus mengevaluasi, memperbaiki, dan memperkuat kapasitas respon krisis dari waktu ke waktu.

Pada level taktis, organisasi yang mengalami dampak positif dari krisis memiliki beberapa kesamaan. Secara signifikan mereka menyatakan pentingnya memberikan perhatian yang substansial tentang ketahanan organisasi, dan menindaklanjutinya dalam langkahlangkah selanjutnya. Sebagian besar menyatakan mereka harus lebih siap untuk menghadarpi krisis berikutnya.

Organisasi yang melakukan peninjauan setelah tindakan secara signifikan dan berkelanjutan, lebih mungkin untuk mengatakan bahwa mereka sangat yakin dengan kemampuan mereka untuk mengimplementasikan pelajaran yang dipetik dari krisis saat ini. Setiap krisis menghadirkan tantangannya sendiri. Tetapi dengan evaluasi diri yang jernih dan kemauan untuk berubah, organisasi dapat membangun ketahanan untuk menghadapi segala jenis krisis dan muncul lebih kuat di sisi lain.

Benang merah krisis pandemi Covid-19 ini adalah, organisasi yang berfokus pada kesehatan para pekerjanya harus berlanjut ketika kehidupan dan bisnis kembali normal. Fokus pada kesehatan adalah jawaban utama dan terpenting yang perlu diambil organisasi dalam merepon pandemi Covid-19. Perubahan moda ke pekerjaan jarak jauh dan menerapkan protokol kesehatan, hingga membantu pekerja yang mengalami kesulitan pribadi selama pandemi, menjadi indikator organisasi yang fokus pada kesehatan dan keselamatan pekerjanya. Mempromosikan kesehatan staf atau karyawan adalah upaya yang tepat. Setelah karyawan memahami bahwa mereka aman dan nyaman, produktivitas dapat meningkat. Kesehatan dalam konteks ini, selain kesehatan fisik, termasuk juga kesehatan psikologis yang timbul akibat tekanan lingkungan kerja, sosial, juga pembatasan yang diterapkan selama pandemi.

Beberapa industri terpukul parah yang lain berhasil berinovasi dan berkembang. Beberapa negara, kota besar, dan kota kecil telah mengalami dinamika yang berbedabeda satu dengan yang lain. Namun, secara luar biasa, para pemimpin bisnis di semua sektor dan wilayah mengatakan langkah paling penting mereka adalah melindungi tim mereka. Mayoritas pemimpin bisnis dan organisasi setuju dan sangat setuju bahwa tanggapan mereka terhadap krisis harus diawali dengan mempertimbangkan kebutuhan fisik dan emosional karyawan mereka.

Dengan pandemi, semakin banyak organisasi di seluruh dunia menggemakan sentimen itu. Sebuah perusahaan produk industri di Australia, misalnya, meluncurkan program jaminan kesehatan mental bagi karyawannya. Perusahaan otomotif di Jerman juga menjamin bahwa pekerjaannya tidak akan diberhentikan. Dengan dukungan organisasi yang lebih kuat, maka ikatan antara manajemen dan karyawan akan semakin erat. Pandemi Covid-19 mengajarkan kepada kita, bahwa menjaga staf dan memastikan kesejahteraan dan moralnya adalah prioritas utama.

\section{Kinerja Pelayanan}

Refleksi alami Pandemi Covid-19 dirasakan hampir semua sektor dalam skala global. Ketidakpastian menghantui, seperti apa masa depan setelah ini. Tata kelola pemerintahan dan pelayanan publik yang selama ini relatif ajek, terbukti tidak cukup teruji. Kondisi serupa juga dialami banyak organisasi di dunia pemerintah maupun swasta. Sekarang kita dipaksa berubah. Pertanyaannya: perubahan seperti apa yang akan kita tuju? Jangan-jangan, respon aksi kita terhadap pandemi, tidak menyentuh fundamental organisasi dalam rangka menciptakan tata kelola yang lebih relevan. 
Alih-alih hanya jeda, lalu kita kembali pada tata kelola dan kebiasaan seperti sebelumnya.

Dari hasil interview terhadap ASN di lingkungan Pemda Provinsi Lampung, semua ASN menyatakan mengaku merasakan adanya perubahan cara kerja selama pandemi. Apel pagi dan absen sidik jari tidak ada lagi. Sistem piket diberlakukan, sehingga tidak semua ASN harus masuk kantor tiap hari. Waktu kerja menjadi lebih fleksibel. Koordinasi kerja antar-ASN dan antar instansi menjadi lebih cepat, sekat birokrasi dan surat-menyurat bisa diatasi dan dipersingkat dengan menggunakan platform digital (wawancara, 17 Juni 2020).

Dengan mekanisme kerja yang baru tersebut, semakin jelas ketimpangan beban kerja dan distribusi tugas antarpegawai. Pegawai yang sudah biasa rajin benar-benar bekerja, semakin kelihatan dan semakin sibuk. Sedangkan pegawai yang biasanya santai, juga semakin tidak jelas pekerjaannya. Kinerja masing-masing individu ASN menjadi semakin kelihatan. Dan, terbukti, sasaran kinerja pegawai yang selama ini rutin dilaporkan melalui sistem e-kinerja, tidak mencerminkan kondisi yang sebenarnya.

WFH memfasilitasi etos kerja ASN, mereka yang memang sebelumnya rajin, akan tetap rajin meski harus mengerjakan pekerjaannya dari rumah, tetapi ASN yang biasanya malas, ya semakin terfasiliasi kemalasannya. Meski dibolehkan bekerja di rumah, biasanya yang malas banyak alasan untuk menghindari pekerjaan atau tugas yang diberikan. Seperti, alasan tidak punya laptop (wawancara, 16 Juni 2020).

Sebagian ASN mengakui kondisi pandemi dengan sistem kerja WFH tidak banyak memengaruhi kinerja instansinya. Pertemuan dan rapat sudah biasa dilakukan melalui online. Meski, acap dirasakan kurang optimal dan cenderung satu arah.
Kontrol kehadiran pegawai (sistem absensi) bisa menggunakan aplikasi digital. Serapan anggaran juga bisa berjalan seperti biasa, meski anggaran kegiatan mengalami rasionalisasi signifikan akibat pandemi. Penerapan PSBB (Pembatasan Sosial Berskala Besar) di sejumlah daerah, juga berdampak tidak terlaksananya perjalanan dinas.

Terkait pelayanan perpajakan, seorang ASN di Badan Pendapatan Daerah (Bapenda) Provinsi Lampung mengakui kinerja pegawai di lembaganya itu tidak terpengaruh pandemi. Meski, mereka harus menyesuaikan cara kerja dengan protokol kesehatan; jaga jarak, pakai masker, rajin cuci tangan. Bapenda adalah OPD di lingkungan Pemerintah Provinsi Lampung yang bertugas mengelola pendapatan daerah. Salah satu sumber pendapatan paling besar menyumbang Pendapatan Asli Daerah (PAD) adalah dari Pajak Kendaraan Bermotor (PKB) dan Bea Balik Nama Kendaraan Bermotor (BBNKB).

Pertengahan Maret 2020, keluar surat Kapolri, yang salah satunya mengatur pelayanan Samsat. Saat awal pandemi, beberapa unit pelayanan Samsat di Bandar Lampung sempat ditutup. Saat itu, pelayanan hanya dibuka di Samsat Induk dan pelayanan cepat (drive thru) di Rajabasa. Samsat keliling di kabupaten tetap dibuka, dengan jam pelayanan dibatasi hanya sampai pukul 12.00. Sebelum pandemi, jam layanan sampai pukul 15.00. Akibatnya, secara keseluruhan jumlah unit layanan Samsat dan jam operasional pelayanan berkurang.

Pengurangan unit layanan dan pemangkasan jam operasional Samsat tersebut, berakibat terjadi penumpukan pengguna layanan di Samsat Rajabasa. Terjadilah penurunan pendapatan yang signifikan dari PKB dan BBNKB. Menurut ASN tersebut, data terakhir saat wawancara, menunjukkan penurunan pembayaran PKB dari target sampai sekitar 30 persen, dan 
penurunan pendapatan BBNKB mencapai sekitar 50 persen. Pendapatan dari sektor ini terus menurun selama pandemi. Padahal, PKB dan BBNKB menjadi penyumbang terbesar PAD Lampung. Pada 2019, misalnya, sumbangan PKB terhadap PAD sebesar 25,11\%, sedangkan sumbangan BBNKB terhadap PAD mencapai 25,68\% (target to target).

Seorang ASN yang bertugas di Dinas Penanaman Modal dan Pelayanan Terpadu Satu Pintu (PM-PTSP) Provinsi Lampung juga mengatakan, selama pandemi pelayanan di kantornya berjalan seperti biasa. Meski, terjadi penurunan jumlah masyarakat yang menggunakan layanan (wawancara, 16 Juni 2020). Dalam memberikan layanan, pemanfaatan teknologi untuk mengurangi tatap muka ditingkatkan. Masyarakat bisa mengurus izin melalui telpon, dan berkas persyaratan bisa dikirim melalui jasa kurir. Jadi sekarang lebih memanfaatkan fasilitas online.

\section{KESIMPULAN}

Fenomena pandemi Covid-19 yang membawa dampak negatif terhadap berbagai sektor dirasakan dalam pemberian layanan publik, sebagaiana terungkap dalam survey persepsi ASN pemberi layanan publik di lingkungan Pemerintah Provinsi Lampung. Mayoritas responden $(83,33 \%)$ menyatakan pandemi Covid-19 berdampak terhadap pelayanan publik. Bahkan seluruh responden (100\%) menyatakan bahwa pandemi Covid-19 berdampak pada manajemen atau tata kelola pelayanan publik. Menurut 58,33\% responden, skala perubahan pelayanan publik yang disebabkan wabah Covid-19 ini adalah dalam skala sedang; sebanyak $41,67 \%$ responden berpendapat perubahan dalam skala yang besar; dan $8,33 \%$ responden berpendapat perubahan terjadi dengan skala yang kecil.

Dalam jangka panjang, bagaimana implikasi pandemi Covid-19 terhadap pelayanan publik? Menurut 58,22\% responden, perubahan pelayanan publik yang terjadi selama masa pandemi ini akan terkait atau berimplikasi pada perbaikan pelayanan publik dalam jangka panjang; $41,67 \%$ responden meyatakan sangat terkait; dan $8,33 \%$ responden menyatakan hanya sebagian saja yang akan berubah dalam jangka panjang, sementara sebagian pelayanan publik akan tetap berjalan sebagaimana sebelum pandemi.

Menurut 50\% responden, perubahan layanan publik selama pandemi Covid-19 ini sebagian akan menjadi permanen, dan sebagian lagi bersifat sementara atau akan kembali seperti dulu sebelum pandemi. Sebanyak 33,33\% menyatakan perubahan selama pandemi ini membawa kita menuju bentuk atau model pelayanan publik yang baru dan lebih baik di kemudian hari. Sedangkan $25 \%$ responden menyatakan perubahan yang terjadi selama pandemi ini hanya bersifat sementara pada saat pandemi saja, dan akan kembali normal seperti sebelum pandemi setelah badai Covid-19 ini bisa diatasi.

Menurut 83,33\% responden, pelayanan publik selama pandemi berpengaruh pada tingkat kepuasan masyarakat terhadap layanan publik yang diberikan; 16,67\% menyatakan sangat berpengaruh; dan 8,33\% responden menyatakan perubahan pelayanan publik akibat pandemi tidak berpengaruh terhadap tingkat kepuasan masyarakat sebagai pengguna layanan publik.

Sebanyak $75 \%$ responden menyatakan, diperlukan peningkatan kualitas pelayanan publik di tempatnya bekerja. Selebihnya, $33,33 \%$ responden menyatakan sangat diperlukan upaya peningkatan mutu pelayanan publik. Artinya, semua responden sepakat, bahwa dibutuhkan upaya serius dan berkesinambungan dalam rangka perbaikan dan meningkatkan kualitas pelayanan publik di setiap organisasi perangkat daerah. 
Menurut mayoritas responden (83,33\%), kapasitas SDM (ASN) pemberi layanan publik paling penting untuk ditingkatkan, agar kualitas pelayanan bisa semakin baik. Sebanyak 58,33\% responden menyatakan sarana-prasarana pendukung layanan publik lebih penting untuk segera ditingkatkan. Selebihnya, menurut 25\% responden, yang paling penting untuk ditingkatkan adalah penggunaan teknologi dengan perangkat penunjang pelayanan publik.

Sementara itu, menurut 58,33\% responden, upaya yang telah dilakukan di unit kerjanya dalam meningkatkan kualitas layanan publik sudah baik; 41,67\% responden berpendapat sudah cukup baik; dan $8,33 \%$ responden berpendapat upaya perbaikan pelayanan publik di unit kerjanya sudah berjalan sangat baik. Sayangnya, $38,46 \%$ responden menyatakan bahwa belum ada mekanisme untuk mengetahui tingkat kepuasan masyarakat pengguna layanan di unit kerjanya. Sementara, jumlah responden yang sama $(38,46 \%)$ menyatakan sudah ada mekanisme untuk mengetahui tingkat kepuasan masyarakat pengguna layanan tersebut, meski itu belum dilakukan secara rutin. Hanya 23,08\% responden yang menyatakan sudah ada mekanisme evaluasi tingkat kepuasan masyarakat terhadap pelayanan yang diberikan, dan itu dilakukan secara rutin dan berkesinambungan.

Keterbatasan dukungan infrastruktur dinilai menjadi aspek paling lemah atau kendala yang dihadapi $58,33 \%$ responden dalam memperbaiki pelayanan publik. Di samping itu, rendahnya komitmen dari penentu/pengambil kebijakan juga masih dirasakan oleh $16,67 \%$ ASN sebagai kendala utama upaya peningkatan mutu layanan publik. Sedangkan 8,33\% responden menyatakan kemampuan atau kapasitas SDM aparatur pelaksana kebijakan dan manajemen operasional pelayanan publik masih dirasakan belum mendukung upaya perbaikan mutu layanan.

\section{DAFTAR PUSTAKA}

khilmi Dzulqornain, (2020). Pendidikan Adab Sebagai Alternatif Pembelajaran Di Masa Pandemi Covid 19. Jurnal Inovasi Pembangunan Volume 08 No. 2.

Almutahar, H. (2014). Pelaksanaan Program Nasional Pemberdayaan Masyarakat (PNPM) Mandiri Pedesaaan Di Kawasan Perbatasan Kabupaten Bengkayang. Universitas Tanjungpura.

I Gusti Agung Rai, (2008). Audit Kinerja pada Sektor Publik; Konsep, Praktik, dan Studi Kasus.

E PRESS, (2008). Collaborative Governance: A New Era of Public Policy in Australia." O'Flynn, Janine dan Wanna, John. The Australian National University (ANU). Australia.

Syafarudin, (2020). Covid-19 dan Disrupsi; Tatanan Sosial, Budaya, Ekonomi, Politik, dan Multi. Bandar Lampung.

Sri Harjanto, (2004). Dari Sistem Inovasi Nasional ke ABG: Catatan Kebijakan Iptek Nasional. Jurnal Inovasi, Vol. 2/XVI.

UNDP, (1997). Governance for sustainable human development. UNDP policy document. New York

Yogi Suwarno, (2008). Inovasi di Sektor Publik.https://www.researchgate.net/p ublication/328202667_INOVASI_DI _SEKTOR_PUBLIK/download

Richardus Eko Indrajit, (2000). Manajemen Sistem Informasi dan Teknologi Informasi. Richardus Eko Indrajit. PT Elex Media Komputindo, Jakarta. 
Parina, Robi Cahyadi Kurniawan, Dedy Hermawan, Ridwan Saifuddin, Annisa

Yulyana Pibiand. AURA, (2021). Pandemi Covid-19 dan Perilaku Politik Masyarakat; Studi Rawan Konflik Pilkada 2020. Bandar Lampung.

John Creswell. London, (2007). Qualiitative Inquiry and Research Design.

Tyran, Jean-Robert, and Rupert Sausgruber (2003). The Diffusion of Policy Innovation: An Experimental Investigation. . Discussion Paper No.2003-14. Department of Economics, Universität St.Gallen.

https://dosen.perbanas.id/penelitiankualitatif-pendekatan-fenomenologi/

https://isnet.or.id/amp/membangun-tatakelola-pemerintahan-yangkolaboratif-collaborativegovernancel.

https://www.ui.ac.id/memaknai-tatakelola-pemerintahan-kolaboratif/ 
Halaman Kosong 